\title{
Antônio Vieira e o panegírico de Santa Teresa: setas de fogo na inteligência*
}

José Américo Miranda

Universidade Federal de Minas Gerais

N

o quarto centenário de nascimento do padre Antônio Vieira é preciso dizer alguma coisa. Não é esta uma data que se possa deixar passar em branco. O poder da oratória de Vieira é tão extraordinário, que ele continua o maior prosador de nossa língua. $\mathrm{Na}$ leitura dele aprenderam a arte de escrever todos os grandes escritores que vieram depois. Sua obra tem sido estudada ou sob as categorias da literatura barroca ou sob as normas da retórica, que o orador dominava como ninguém. O que vou dizer aqui não é novo, data, em sua maior parte, do século XVII - são palavras do próprio Vieira. Vou citá-lo longamente - e espero, com isso, fazer justiça à excelência de sua prosa.

Antes, porém, só uma palavra sobre o título que dei a esta fala - já que foi preciso anunciá-la. Santa Teresa foi ferida no coração por um serafim com uma seta de fogo - e incendiou-se de amor. Este éo instante representado por Bernini na famosa estátua "Santa Teresa em êxtase". Por analogia a esse incêndio amoroso, tomei a seta de fogo emprestada ao serafim para com ela

* Este texto foi lido, na Faculdade de Letras da UFMG, numa sessão comemorativa dos 400 anos de nascimento do padre Vieira. Entendeu o autor que a maior homenagem que se poderia fazer ao grande artista da Língua Portuguesa estaria no largo emprego de palavras do próprio homenageado; daí o excessivo das citações e das apropriações (muitas vezes sem aspas), que os admiradores e conhecedores da obra do padre logo reconhecerão. As indicações de página referem-se à edição consultada dos Sermões e das Cartas. 
atingir o engenho de Vieira - que teve sua inteligência verbal como que incendiada por setas de fogo. É o que veremos.

Pediu-me acaso a professora Silvana Pessôa uma palavra sobre o padre Antônio Vieira, em comemoração aos 400 anos de seu nascimento. "E quantas vezes os que pareceram acasos, foram conselhos altíssimos da Providência Divina! Acaso parece que estava Cristo encostado sobre o poço de Sicar; e era conselho da Providência Divina, porque havia de chegar ali uma mulher (a Samaritana) que se havia de converter. Acaso parece que entrava Cristo pela cidade de Naim; e era conselho da Providência Divina; porque havia de sair dali um moço defunto, que havia de ressuscitar. Acaso parece que passeava Cristo pelas praias do mar de Galiléia; e era conselho da Providência Divina, porque havia de chamar dali a dois pescadores, que, deixadas as redes e o mundo, O haviam de seguir." (t.VIII, p. 357) Acaso e bem acaso um dia decidi deixar minha primeira profissão [de médico] pela de professor; acaso e bem acaso aceitei um dia o convite que me fez a professora Silvana para vir até aqui dizer estas palavras. Acaso e bem acaso, escolhi para tema de minha exposição o "Sermão de Santa Teresa", pregado pelo padre no ano de 1654. "E quem me disse a mim, nem a vós, se debaixo destes acasos se oculta algum grande conselho da Providência Divina?" (t.VIII, p. 357-358)

Andava o padre Vieira no Maranhão desde os primeiros dias do ano de 1653. Na ilha do Maranhão, segundo João Lúcio de Azevedo (t.I, p.228), naquele tempo "havia quatro povoações de índios, ali estabelecidos em tempo anterior, cristãos pelo batismo, mas pela ausência dos missionários deixados a si, sem guias que lhes amparassem os incertos passos na vida civilizada. Desta, na verdade, conheciam somente alguns dos vícios, a servidão imposta e a tirania dos homens." Os últimos padres, que haviam cuidado dos índios no tempo anterior à chegada de Vieira, tinham sido mortos em 1649 pelos mesmos índios de que cuidavam. A situação dos indígenas é assim descrita pelo mesmo autor, já citado (t.I, p. 229): 
"Governados por um capitão, quase sempre mestiço, cuja missão consistia em evitar que fugissem, e determinar quais deles, a cada requisição, tinham de entrar no serviço das autoridades e moradores, decresciam em número progressivamente, sucumbindo ao trabalho excessivo, aos maus tratos, a moléstias adquiridas no contato de seus opressores, inócuas para estes às vezes, quase sempre fatais para eles." No cuidado dos índios, andou o padre Vieira pelas matas, viajou de barco ao Pará, de onde navegou pelo rio Tocantins acima, e foi a Marajó - grande ilha a que chamavam ilha de Joanes. Em suas cartas, pedia ele mais missionários para a enormidade do serviço.

Tendo chegado ao Maranhão no início de 1653, vindo da corte, onde se acostumara às mais altas rodas, tendo embarcado na esperança, até a última hora, de que o rei o mandaria desembarcar e permanecer em Lisboa a seu serviço - apesar de tudo dedicou-se o padre com afinco ao cuidado dos índios. Logo ele percebeu a dimensão do problema: teria contra si a totalidade dos colonos, que lucravam com a exploração dos índios. Mas, inspirado, como veremos, pelo menos em parte, em Santa Teresa, deu novo rumo à sua vida, na esperança da salvação própria e dos outros. Em carta de 6 de maio de 1653 ao padre Francisco de Morais, fala o padre de si e de suas atividades: "Ando vestido de um pano grosseiro cá da terra mais pardo que preto; como farinha de pau; durmo pouco; trabalho de pela manhã até à noite; gasto parte dela em me encomendar a Deus; não trato com mínima criatura; não saio fora senão a remédio de alguma alma; choro meus pecados; faço que outros chorem os seus; e o tempo que sobeja destas ocupações levam-no os livros da madre Teresa e outros de semelhante leitura." (t.I, p. 295)

Aí já encontramos Teresa de Ávila, ou Teresa de Jesus, madre Teresa, na esfera dos pensamentos do padre. Inspirava-se nela e em sua obra o grande orador, na esperança de superar a dor e o desconsolo em que se encontrava nas terras hostis. A opiniāo do padre, para que se resolvesse definitivamente o problema administrativo relacionado aos indígenas, nas palavras do mesmo João Lúcio de Azevedo (t.I, p. 249), era esta: "O só remédio estava em se isentarem as missões e os índios de toda a interferência das autoridades." Naturalmente, segundo essa proposta, o poder único a ser exercido sobre 
eles, os índios, seria o dos jesuítas. Para conseguir isso, decidiu o padre Vieira, em acordo com seus companheiros, voltar ao reino, para fazer os requerimentos necessários. Antes, porém, de partir, pregou, no dia 13 de junho de 1654, na festa de Santo Antônio, o célebre sermão aos peixes, em que figurava nas criaturas do mar os habitantes da terra do Maranhão.

Esse o contexto remoto do Sermão de Santa Teresa. Do contexto imediato nos dá notícia o próprio Vieira, no mesmo Sermão.

\section{II}

Poucos dias depois de haver pregado o Sermão de Santo Antônio, ainda em junho de 1654, embarcou o padre Vieira para Lisboa. Não foi feliz a viagem, mas deu motivo ao rasgo de eloqüência com que o padre dá início ao Sermão de Santa Teresa, pregado no colégio da Companhia de Jesus, na ilha de S. Miguel. Depois de sessenta dias de viagem, quando passava pela altura dos Açores, esteve o navio a ponto de naufragar, batido por enorme tempestade. $\mathrm{O}$ navio chegou a adernar, ficando uma das bordas mergulhada na água, de modo que os passageiros tiveram de se agarrar, da forma que puderam, na amurada oposta. O navio apenas flutuava, com os mastros perdidos, com as enxárcias rotas, quando, um pouco amainada a tempestade, surgiu no horizonte uma esperança. Mas veio a noite e sumiu o navio. Na manhã seguinte, descobriu-se: tratava-se de um corsário holandês, interessado na carga que transportavam. Os embarcados foram deixados numa ilha, de onde passaram à ilha de São Miguel, onde foi pregado o sermão. O barco deles foi levado pelos holandeses, com a carga de açúcar e todos os pertences de todos os desembarcados. Do padre Vieira consta que foram levados alguns livros e alguns papéis.

No exórdio do Sermão de Santa Teresa, que calculo sem medo se possa dizer que é impetuoso e veemente, atribui o sermonista a série de acasos que o trouxe àquela ilha à ação da Providência Divina - que, naquele caso, usara os meios da Natureza para obrar seus efeitos -; e ele se diz vomitado das ondas, como São Paulo na ilha de Malta e, mais remotamente ainda, como Jonas em sua missão a Nínive. Eis a notícia que nos dá, no sermão, do naufrágio recente: "Por certo que não foi tão grande 
a tempestade de Jonas, como a em que eu e os companheiros nos vimos. O navio virado no meio do mar, e nós fora dele pegados ao costado, chamando a gritos pela misericórdia de Deus, e de sua Mãe. Não apareceu ali baleia que nos tragasse, mas apareceu (não menos prodigiosamente naquele ponto) um desses monstros marinhos que andam infestando estes mares: ele nos tragou, e nos vomitou depois em terra." (t.VIII, p. 358-359)

Apresenta-se o exórdio em harmônica concordância com o restante do discurso, a começar pelos paralelos bíblicos. Ao longo desta exposição, deixarei de lado esses paralelos, com algumas poucas exceções, para não tornar excessivamente longa a exposição. Estamos ainda no exórdio, cuja função é essencialmente fática: destina-se tornar dócil, atento e benevolente o auditório. (Cf. Reboul, p. 55)

De início, o sermonista obtém a atenção pela veemência, fazendo ver, desde suas primeiras palavras, que obra a Providência nas circunstâncias do discurso - acasos, naufrágios, forças da natureza, tudo posto e disposto conforme aos desígnios dela. E desse conjunto de circunstâncias resulta o sermão. Por acaso encontra-se o padre naquela ilha; por acaso a tempestade os abateu; por acaso o corsário holandês os recolheu e "vomitou" na praia. Havia, portanto, como nos acasos bíblicos que o padre menciona logo no começo de seu sermão (citados no início desta prática) - havia, por força, de seguir-se algo de extraordinário.

O padre obtém a benevolência pela humildade que afeta: primeiro é joguete das ondas, depois declara a Santa Teresa que tem a alma dura e fria. Por isso, pede a ela que lhe alcance, por intercessão à Virgem Santíssima, "aquela graça que acende as vontades; aquela graça que abranda, que rende, que fere, que inflama os coraçóes." (t.VIII, p. 360) Quando se compara a São Paulo, diz: "Bem conheço quão falto estou da eloqüência, e muito mais do espírito de S. Paulo; mas na ocasiāo e nas circunstâncias presentes, ninguém me poderá negar uma grande parte de pregador, que é chegar a esta ilha vomitado das ondas." (t.VIII, p. 358)

O orador, no capítulo segundo, reduz o auditório à docilidade, expondo o caminho por onde o há de conduzir: faz uma exposição clara e breve da questão de que tratará.

A harmônica concordância com o restante do discurso guarda o 
exórdio em sua própria estrutura. Nas primeiras palavras encontra-se o pregador sujeito às forças e aos acasos da natureza, está no mais baixo dos mundos, sujeito a naufrágios e a soterramentos. Parara numa ilha de origem vulcânica e a numa cidade que, nas palavras dele "se se sovertesse (o que Deus não permitirá), podia ser castigo sem ser milagre”, (t.VIII, p. 359) porque seria o comum da natureza num lugar como aquele. Nas palavras seguintes pede graça à Gloriosa Teresa, e por meio dela à Mãe de Deus: está no mais alto dos mundos. Ele pede graça: "um raio da vossa luz, e um assopro do vosso espírito!" (t.VIII, p. 359) Por fim, põe os olhos no Evangelho, que, como veremos, representa aqui o meio do caminho entre o alto e o baixo. E se imaginarmos um caminho que ligue o alto ao baixo, por ele tanto se poderá subir, como se poderá descer - que uma escada serve para tudo: tanto nos eleva como nos faz baixar, tanto serve para a escalada como para a descida ou a queda.

O profeta Jonas ameaçara Nínive: "Ainda quarenta dias, e Nínive será destruída." (Jn 3,4) Pensou o orador, dadas as circunstâncias, em tomar essas palavras para tema de seu discurso, mas ponderou: "Supostas todas estas circunstâncias, mui a propósito vinha o tema ao pregador e ao lugar; mas é o dia mui de festa para assunto tão triste e tão funesto." (t.VIII, p. 359) Era o dia em que se celebrava Santa Teresa-devia ser um dia 15 de outubro -, e o pregador tomou o tema ao evangelho de São Mateus, no capítulo em que narra a parábola das dez virgens: "Cinco eram insensatas e cinco, prudentes." (Mt 25,2) Com isso, comprometeu o pregador todo o auditório na pregação.

Eis com que palavras ele o faz: "Com os olhos no Céu, com os olhos na Terra, e com os olhos no Evangelho determino pregar hoje, que é o modo com que nas festas dos Santos se deve pregar sempre. Deve-se pregar com os olhos no Céu, para que vejamos o que havemos de imitar nos Santos: deve-se pregar com os olhos na Terra, para que saibamos o que havemos de emendar em nós: e deve-se pregar com os olhos no Evangelho, para que o Evangelho, como luz do Céu na Terra, nos encaminhe ao que havemos de emendar na Terra, e ao que havemos de imitar no Céu. O que hoje nos põe diante dos olhos o Evangelho, são dez virgens, cinco néscias, e cinco prudentes... [...] As prudentes, vistas com os olhos no Céu, parecem- 
me néscias; e as néscias, vistas com os olhos na Terra, parecem-me prudentes. Isto é o que se me afigura hoje, e esta será a matéria do sermão - que as prudentes vistas com os olhos no Céu, foram néscias; e que as néscias, vistas com os olhos na Terra, foram prudentes. Mais claro. Que as virgens prudentes comparadas com Santa Teresa, foram néscias: [...] e que as virgens néscias comparadas conosco foram prudentes [...].” (t.VIII, p. 360-361)

Reparem que Santa Teresa está acima das virgens prudentes; que as prudentes estão acima das néscias; e as néscias, acima de nós. Há quatro degraus nessa escala; e todo o sermão será construído à maneira de uma escada: de degrau em degrau.

Descrevamos a estrutura do sermão: ele é composto de dez partes, a que chamarei capítulos. Os dois primeiros constituem o exórdio. Os capítulos III a IX tratam das quatro diferenças entre as virgens prudentes e Santa Teresa - os olhos do pregador estão voltados para o Céu; o capítulo $\mathrm{X}$, peroração, trata das oito diferenças entre as virgens néscias e nós - os olhos do pregador estão voltados para a Terra.

Os capítulos III, IV e V - são três os capítulos - tratam da primeira coisa em que as virgens prudentes foram néscias se comparadas a Santa Teresa; os capítulos VI e VII tratam da segunda coisa em que as virgens prudentes foram néscias, se comparadas a Santa Teresa; o capítulo VIII trata da terceira coisa em que as virgens prudentes foram néscias, se comparadas a Santa Teresa; o capítulo IX trata da quarta coisa em que as virgens prudentes foram néscias, se comparadas a Santa Teresa. Por fim, o capítulo $\mathrm{X}$ trata das oito diferenças entre nós e as virgens néscias, dos oito pontos em que nós, comparados às virgens néscias, somos néscios.

Os degraus do interesse do pregador são visíveis nessa enumeração: quanto mais alto o assunto, tanto mais ele se desdobra na elaboração dele. Tanto é assim que as quatro comparações entre as virgens prudentes e Santa Teresa, em todos os casos para dizer que em relação à Santa as virgens foram insensatas, ocupam os sete capítulos centrais do sermão, ao passo que as oito comparaçôes entre as virgens insensatas e nós, em todos os casos para dizer que nós, comparados a elas, somos insensatos, ocupam o décimo capítulo, que cumpre na estrutura do sermão a função de peroração. Pois a peroração 
é a última oportunidade de que dispõe o orador para influir no ânimo de seus ouvintes, para convertê-los à sua causa. "A peroração é o momento por excelência em que a afetividade se une à argumentação, o que constitui a alma da retórica." (Olivier Reboul, p. 60) Portanto, oito degraus num só capítulo - quando antes se gastaram ora três, ora dois, ora um capítulo para apenas um degrau. Brevidade e condensação destinadas a um efeito máximo. "Pra baixo, todo santo ajuda" - como diz o ditado popular.

\section{III}

Uma das perguntas que nos aflige é a seguinte: por que ler o padre Vieira hoje? Deixando de lado o domínio da língua - quero crer que ninguém nunca o teve com aquela desenvoltura -, a grande razão para o lermos consiste em ser ele um dos maiores artistas (se não for o maior) da língua portuguesa. Artista no sentido pleno da palavra: artista, porque põe em linguagem figurada os assuntos de que trata; artista, porque dá uma forma concreta ao seu tema - já mencionamos a forma escalonada do Sermão de Santa Teresa. Nesse sermão panegírico a uma santa cuja experiência mística foi capital para sua santidade, tratando dos contatos que teve ela com o que há de mais alto no Céu, dispôs ele em figura de escada a sua argumentação. Isso no plano da estrutura ou da organização geral do discurso. E há mais razões para isso. Razões que remontam às origens do culto a Nossa Senhora do Carmo.

Diz a lenda que o culto a Nossa Senhora do Carmo é um dos quatro - e creio que não é acaso o aparecimento desse número - anunciados muitos séculos antes da vinda de Cristo ao mundo. O templo do Monte Carmelo é justamente o quarto dos antigos templos dedicados à Mãe de Deus. Dizem que ao profeta Elias não só foi revelado o nome de Maria, mas, também, que ele edificou um templo dedicado a ela. Uma outra tradição, relativa à mesma matéria, admite que um grupo de homens devotos dos profetas Elias e Eliseu foram preparados por S. João Batista para o advento do filho de Deus e erigiram à Virgem um santuário no Monte Carmelo. Mas foi no século XII que o monge Bertoldo, com alguns companheiros, 
se estabeleceu naquele lugar. "Não se sabe se encontraram lá a Congregação dos Servos de Maria, ou fundaram uma com este nome; certo é que receberam uma regra rigorosíssima." (Augusto de Lima Júnior, p. 66)

Além da simetria implícita no número 4 e própria dele, o profeta Elias, cujo nome se associa remotamente ao culto de Nossa Senhora do Carmo, não morreu propriamente - foi arrebatado ao céu num carro de fogo.

Quero crer que todo esse conjunto de idéias habita o sermão e determinou sua estrutura - com destaque para a harmonia do número $4 \mathrm{e}$ para as idéias de ascensão e de seu correlato implícito, a descida ou a queda. E acaso quis ou determinou a Providência que esta fala se fizesse - justamente - no quarto centenário de nascimento do padre Antônio Vieira.

Foi santa Teresa, nascida em 1515 e morta, aos 67 anos de idade, em 1582, com o concurso de São João da Cruz, a autora de uma reforma na ordem do Carmo - introduzindo a distinção entre "carmelitas descalços" - os que aceitaram a reforma de Santa Teresa e os "carmelitas observantes" - que continuaram fiéis às regras primitivas.

\section{IV}

"Cinco eram insensatas e cinco, prudentes" - dizem as palavras que o pregador tomou por tema para o sermão. São palavras da "Parábola das dez virgens" - Evangelho segundo São Mateus, capítulo 25. Essa parábola termina pela seguinte advertência: "Vigiai, portanto, porque não sabeis nem o dia nem a hora." Trata-se de uma alusão ao instante em que será decidido o destino de cada um de nós; uma alusão ao instante de nossa morte. Esse tema fez o pregador iniciar seu argumento pelo seguinte tópico: "A primeira cousa em que as virgens prudentes, comparadas com Santa Teresa, foram néscias." (t.VIII, p. 361) E começou por uma agudeza: a distinção entre "instante", por um lado, e "tempo", por outro - o que fez com engenho extraordinário. Vejamos.

Eu disse há pouco que uma das perguntas que nos aflige é esta: por que ler o padre Vieira hoje? Eu disse, também, que ele põe em linguagem figurada os assuntos de que trata - e que isso significa dar tratamento 
artístico à matéria pensada. Vou fazer uma comparação: a distinção entre "instante" e "tempo" feita por um filósofo e essa mesma distinção feita pelo padre Vieira, no terceiro capítulo do Sermão de Santa Teresa.

Primeiro, o filósofo - Jean-Paul Sartre (p.158): “A temporalidade é evidentemente uma estrutura organizada, e esses três pretensos 'elementos' do tempo, passado, presente, futuro, não devem ser encarados como uma coleção de 'dados' ('data') cuja soma deve ser efetuada - como, por exemplo, uma série infinita de 'agoras' na qual uns ainda não são, outros não são mais -, e sim como momentos estruturados de uma síntese original. Senão, vamos deparar antes de tudo com este paradoxo: o passado não é mais, o futuro não é ainda; quanto ao presente instantâneo, todos sabem que não existe: é o limite de uma divisão infinita, como o ponto sem dimensão."

Agora, o padre Vieira: "A primeira cousa em que as virgens prudentes, comparadas com Santa Teresa, foram néscias, é, que as virgens prudentes dormiram quando tinham obrigação de vigiar; e Santa Teresa vigiou quando tinha segurança para dormir. A obrigação que todas as virgens tinham de vigiar, declarou Cristo no fim do Evangelho, quando disse: Vigilate, quia nescitis diem, neque horam: Vigiai, porque não sabeis o dia, nem a hora. Mas poderá alguém replicar, e não sem fundamento, que estas virgens, ainda que não sabiam a hora, ao menos sabiam o dia, porque foram convidadas para o dia das bodas. Contudo, é certo que não sabiam, nem o dia, nem a hora: não sabiam a hora em que havia de vir o Esposo, porque havendo muito que esperavam, veio à meia-noite: Media autem nocte: e não sabiam o dia; porque quem veio à meia-noite, se viera um pouco antes, vinha em um dia, e se viera um pouco depois, vinha em outro. E como o Esposo veio ao ponto da meia-noite, em que um dia natural acaba e o outro começa, ainda depois de vir, não se sabe em que dia veio. Não se sabe se foi no dia de antes ou no dia de depois; nem se sabe se foi em ambos os dias, ou em nenhum deles, porque o ponto da meia-noite é instante, e aquele instante não é parte de nenhum dos dias, porque não é tempo, etc." (t.VIII, p.361)

Notável diferença: o filósofo pensa abstratamente, lança mão do conceito matemático de ponto, da noção de limite ("limite de uma divisão infinita"), da noção de infinito - tudo noções que não podem ter 
representação concreta, mas apenas representação pensada, conceitual. Notável diferença: o padre Vieira nos revela de outro modo a natureza do instante; no comentário e na glosa da alegoria da parábola, ele o representa para nós com elementos de nossa vivência; ele nos dá dele uma compreensão que parte da experiência sensível, da representação concreta, em figura, para, assim, nos elevar à idéia do instante - que não é figura. Notável diferença: convenhamos - obra de artista.

Um parêntese, para leitura de um breve poema de Octavio Paz (p.45 - tradução nossa), em que o mesmo tema é abordado - segundo fragmento de "Apuntes del Insomnio":

No átimo do instante, me disse: "Já sou eterno na plenitude do tempo."

E o instante se caía em outro, abismo sem tempo.

Fechado o parêntese, de volta ao Sermão de Santa Teresa: toda a argumentação em torno do "saber o dia e a hora" destinou-se à primeira das quatro demonstrações da superioridade de Santa Teresa em relação às virgens prudentes do Evangelho. $\mathrm{O}$ argumento tem por fundamento o fato de as virgens, todas elas, néscias e prudentes, terem adormecido enquanto esperavam a chegada do noivo; ao passo que Santa Teresa não dormiu. Diz o pregador: "Enfim, as virgens prudentes, comparadas com as néscias, foram prudentes, porque tiveram mais prevenção; mas comparadas com Santa Teresa, foram néscias. Por quê? Porque elas dormiram, tendo obrigação de vigiar, pois não sabiam nem o dia, nem a hora: e Santa Teresa vigiou, tendo segurança para dormir; porque sabia o dia e a hora, e ainda mais." (t.VIII, p.362-363)

O pregador, nessa passagem, toca na "maior maravilha” de Teresa, que consistiu no seguinte: "Um dos maiores favores que Santa Teresa recebeu de Deus, e em que excedeu a todos ou quase todos os Santos, foram dois secretos que o mesmo Senhor lhe revelou, ocultos a todos os homens: o primeiro, quando havia de morrer; o segundo, que se havia de salvar." (t.VIII, p. 363) Por isso disse ele "que Santa Teresa vigiou sabendo mais que 
o dia, e mais que a hora: soube o dia e a hora, porque soube quando havia de morrer, e soube mais que o dia, e mais que a hora, porque soube também que morrendo se havia de salvar." (t.VIII, p. 363)

Nesse degrau mais alto da escada, em que se armou o sermão, há outra subdivisão em quatro, como se aqui - nesse nível - fossem enormes, se não infinitas, as distâncias: acima de todos está Deus-pai, onisciente e todo-poderoso; entre Ele e Santa Teresa está o Filho, que se fez homem e teve, como Santa Teresa, as duas ciências que para os outros Santos foram, como para nós, duas ignorâncias - "Todos os homens neste mundo vivemos com duas ignorâncias; a primeira, da morte, a segunda, da predestinação." (t.VIII, p. 363) "Porém a Santa Teresa tratou-a Deus com tal exceção e fez da lealdade do seu amor tão diferente confiança, que em lugar destas duas ignorâncias, lhe deu as duas ciências contrárias: a ciência de quando havia de morrer, e a ciência de que se havia de salvar; porque sabia que nem a ciência e certeza da hora da morte, lhe havia de diminuir a vigilância, nem a ciência e segurança da salvação lhe havia de entibiar o cuidado." (t.VIII, p. 364) As mesmas duas ciências teve Cristo, quando viveu entre os homens: Ele sabia quando iria morrer; e sabia que iria ao encontro do Pai. As mesmas duas ciências teve Santa Teresa. Diz o pregador: "Ah prudentíssima virgem Teresa, que com este dobrado sciens, com estas mesmas duas ciências fizestes néscias as que o Evangelho canoniza de prudentes! [...] As duas ciências que Cristo tinha por natureza e por graça, tinha Santa Teresa por revelação." (t.VIII, p.366)

E como alcançou Santa Teresa, ela só, esse degrau altíssimo, acima até mesmo de outros Santos? Depois de assinalar as práticas de penitência e de virtudes por Santa Teresa, desde sua infância; depois de ter-se ela submetido em vida a todos os rigores; depois de ter feito por sua salvação o que fizeram os maiores Santos; depois de ter despido os vestidos da religião moderada e descalçado os pés (na reforma da ordem do Carmo, obra sua); depois de ter-se retirado totalmente do trato humano e ter gastado toda a vida em oração e união tão alta com Deus; depois de ter-se calado e não respondido uma palavra sequer contra os que a infamaram e perseguiram; depois de ter não só perdoado seus inimigos, mas orado eficazmente por eles e tendo alcançado favores de Deus para eles; depois de 
chorar todos os pecados que não tinha, como se os tivesse... depois de chamar todas essas circunstâncias da vida de Santa Teresa à lembrança de seu auditório, diz ainda o pregador: "Até aqui, Teresa, as imitações de vosso Esposo. Não sei se passe daqui; mas quero passar, pois Ele quis que vós passásseis. Que tenha Teresa o Céu seguro, e que quando mais a apertavam as dores terríveis de suas enfermidades, pedisse a Deus lhas dilatasse até o fim do mundo? Que tenha Teresa o Céu seguro, e que viva com tanto escrúpulo e delicadeza de consciência, que não cometesse nem um pecado venial, com advertência? [...] Finalmente, que tenha Teresa o Céu seguro, e que se vá livremente a padecer as penas do Inferno em vida, porque as não havia de padecer depois da morte? Esta circunstância é, gloriosa Teresa, a que faz singulares vossas vitórias, ainda aquelas em que outros Santos se pareceram convosco. Eles obraram, e vós obrastes: mas eles, como nós, incertos da morte; vós, como Cristo, com certeza da vida: eles, como nós, com o Céu duvidoso; vós, como Cristo, com o Céu seguro: eles, como nós, entre o temor da morte, e do Inferno; vós, como Cristo, livre e superior a todos os temores." (t.VIII, p. 367-368)

Mais um detalhe ainda, para a glória de Santa Teresa. A santidade e a virtude, quando são exercidas, têm no temor a Deus um de seus componentes. Todos temem a Deus. Todos vivem no temor de Sua Justiça. Mas, perante Santa Teresa, o Senhor se despiu de sua Justiça. "Os outros grandes amadores de Deus, amam a Deus com todos seus atributos: Santa Teresa amou a Deus com um atributo menos. Revelando Deus a Santa Teresa que era predestinada, e que se havia de salvar, ficou Deus para com Teresa como se não tivera justiça; porque suposto o decreto da predestinação, nem a Justiça Divina a havia de condenar, nem podia. E amar a Deus com o atributo da Justiça menos, é o mais a que podia chegar a fineza e a fidalguia do amor." (t.VIII, p. 370)

A fineza, palavra tão cara aos prosadores e poetas do século XVII, conforme lembra Sor Juana Inés de la Cruz (Cf. p. 415-416), conhece dois termos: o que a executa e o que a recebe. Da parte do amante, a fineza será grande pelo muito esforço que lhe custar; da parte do amado, a fineza será grande pela muita utilidade ou benefício que lhe trouxer. Que benefício 
pode alguém fazer a Deus, senão amá-lo com perfeição? - poderíamos perguntar. Sobre os dois extremos dessa fineza, diz o padre Vieira: "Para Teresa amar mais perfeitamente a Deus, e para Deus ser mais perfeitamente amado, Deus (digamo-lo assim) despiu-se de um atributo, e Teresa de uma virtude: Deus pôs de parte o atributo da justiça. Teresa pôs de parte a virtude do temor: e como Deus esteve com menos este atributo, e Teresa com menos esta virtude, nestes dois menos consistiu a perfeição de mais amar, e de ser mais amado: em Deus a perfeição de ser mais amado, porque foi amado sem ser temido: em Teresa a perfeição de mais amar, porque amou sem temer." (t.VIII, p. 371)

Assim, pois, neste último andar da estrutura escalonada do sermão, patamar de infinitas distâncias, impóe-se esta divisão em quatro níveis: Deus-Pai; Seu Filho; Santa Teresa; todos os outros Santos. Lugar privilegiado, o que foi reservado a Santa Teresa - pela fineza de seu amor, que se igualou ao do Filho de Deus e se exerceu em circunstâncias prodigiosamente semelhantes àquelas em que Ele, o Filho de Deus, viveu o seu amor ao Pai.

\section{V}

No passo seguinte do sermão, o orador se empenha na demonstração de outra sutileza: essa parte, composta pelos capítulos V e VI, é um vasto campo para o exercício da agudeza. No início do capítulo V, passa o orador à segunda etapa do movimento escalonado do Sermão: "A segunda cousa em que as virgens prudentes, comparadas com Santa Teresa foram néscias, é que as prudentes em matéria de salvação quiseram só o que basta: e Santa Teresa quis mais do que sobeja." (t.VIII, p. 372)

Quando as virgens do Evangelho foram acordadas, pelo aviso de que o noivo estava chegando, viram-se as néscias sem azeite - todo o que haviam trazido consigo se queimara enquanto dormiam. Elas pediram às prudentes um pouco do delas, que haviam trazido suas reservas; mas as prudentes as mandaram ir comprar mais - não haveriam de se arriscar por elas. As prudentes foram nisso prudentes, mas, diz o orador, que foram insensatas. Diz ele: "Mas néscias, quando em matéria tão importante não querem dar 
o que duvidam se lhe bastaria, ou não bastaria? Sim; e por isso mesmo. Por duvidarem, se bastaria, ou não bastaria, quando haviam de duvidar, se sobejaria ou não sobejaria; porque em matéria de salvação, só o que sobeja é bastante; o que basta, não basta.” (t.VIII, p. 372-373)

Está colocado o problema: em matéria de salvação, "o que basta, não basta." Foi Vieira exímio no discernimento dessas agudezas, em que algo é comparado consigo mesmo - e, nessa comparação, o termo comparado resulta maior ou menor que ele próprio. Pode-se demonstrar isso com palavras do próprio Vieira, em outra ocasião.

No Sermão do Mandato pregado em 1643, em que tomou por tema "os remédios do amor e o amor sem remédio", pregou ele o seguinte: "Os remédios do amor, e o amor sem remédio são as quatro coisas, e uma só... [...]. O primeiro remédio que dizíamos é o tempo. Tudo cura o tempo, tudo faz esquecer, tudo gasta, tudo digere, tudo acaba. Atreve-se o tempo a colunas de mármore, quanto mais a corações de cera? São as afeiçóes como as vidas, que não há mais certo sinal de haverem de durar pouco, que terem durado muito. São como as linhas, que partem do centro para a circunferência, que quanto mais continuadas, tanto menos unidas. Por isso os Antigos sabiamente pintaram o amor menino; porque não há amor tão robusto que chegue a ser velho. De todos os instrumentos com que o armou a natureza, o desarma o tempo. Afrouxa-lhe o arco, com que já não tira; embota-lhe as setas, com que já não fere; e faz-lhe crescer as asas, com que voa e foge. [...] O segundo remédio do amor é a ausência. Muitas enfermidades se curam só com a mudança do ar; o amor com a da terra. É o amor como a Lua, que em havendo Terra em meio, dai-o por eclipsado. À sepultura chamou David discretamente, terra do esquecimento: Terra oblivionis. E que terra há que não seja a terra do esquecimento, se vos passastes a outra terra? Se os mortos são tão esquecidos, havendo tão pouca terra entre eles e os vivos; que podem esperar e que se pode esperar dos ausentes? Se quatro palmos de terra causam tais efeitos; tantas léguas que farão? Em os longes passando de tiro de seta, não chegam lá as forças do amor. [...] O terceiro remédio do amor, é a ingratidão. Assim como os remédios mais eficazes são ordinariamente os mais violentos; assim a 
ingratidão é o remédio mais sensitivo do amor, e juntamente o mais efetivo. A virtude que lhe dá tamanha eficácia, se eu bem o considero, é ter este remédio da sua parte a razão. Diminuir o amor com o tempo, esfriar com a ausência, é sem-razão de que todos se queixam; mas que a ingratidão mude o amor e o converta em aborrecimento, a mesma razão o aprova, o persuade, e parece que o manda. Que sentença mais justa, que privar do amor a um ingrato? O tempo é natureza, a ausência pode ser força, a ingratidão sempre é delito. Se ponderarmos os efeitos de cada um destes contrários, acharemos que a ingratidão é o mais forte. $\mathrm{O}$ tempo tira ao amor a novidade, a ausência tira-lhe a comunicação, a ingratidão tira-lhe o motivo. [...] É pois o quarto e último remédio do amor, e com o qual ninguém deixou de sarar, o melhorar de objeto. Dizem que um amor com outro se paga, e mais certo é, que um amor com outro se apaga. Assim como dois contrários em grau intenso não podem estar juntos em um sujeito; assim no mesmo coração não podem caber dois amores; porque o amor que não é intenso, não é amor. Ora grande coisa deve de ser o amor, pois sendo assim, que não bastam a encher um coração mil mundos, não cabem em um coração dois amores. Daqui vem, que se acaso se encontram e pleiteiam sobre o lugar, sempre fica a vitória pelo melhor objeto. É o amor entre os afetos, como a luz entre as qualidades. Comumente se diz, que o maior contrário da luz são as trevas, e não é assim. O maior contrário de uma luz é outra luz maior. As estrelas no meio das trevas luzem, e resplandecem mais; mas em aparecendo o Sol, que é luz maior, desaparecem as estrelas. [...] Em aparecendo o maior e melhor objeto, logo se desamou o menor." (t.IV, p. 287-312)

A luz é o maior contrário da própria luz. Teremos adiante a demonstração - um tanto semelhante a esse exemplo - de que, em matéria de salvação, o que basta não basta.

No Sermão de Santa Teresa, argumenta o pregador que as virgens, enquanto dormiam, poderiam ter mantido acesa apenas uma das lâmpadas; economizariam muito azeite se procedessem assim. Entretanto, a palavra do Evangelho é parábola: ela quer dizer outra coisa. E dizem os doutores da igreja que o lume daquelas lâmpadas é a graça de Deus, e o óleo (ou o 
azeite) são as obras nossas. Sem o concurso dessas duas coisas, não há salvação. Diz ele: "As alâmpadas de fogo material podem-se acender umas com o fogo das outras e podem-se acender naquele ponto estando apagadas até então: porém as alâmpadas da graça e da salvação não ardem com fogo alheio, senão com o próprio; e se não estão e perseveram acesas de antes, não se podem acender depois. Cuidar alguém que há de ter a alâmpada apagada toda a noite, e que a há de acender quando vier o Esposo: cuidar alguém que há de estar em pecado toda a vida, e que se há de pôr em estado de graça na hora da morte; é engano do Demônio, e injúria que se faz à justiça e misericórdia e Deus." (t.VIII, p.375) E argumenta ainda que os auxílios de Deus são, uns suficientes, outros eficazes - e que sem eficácia, os auxílios suficientes não bastam. Nessa linha de raciocínio, prossegue ele: "Para um homem se salvar, basta morrer bem; e para morrer bem é necessário mais alguma coisa? É necessário viver bem. Logo para um homem em matéria de salvação ter o que basta, é-lhe necessário muito mais do que basta; porque para se salvar, é-lhe necessário morrer bem, que é muito; e para morrer bem, é-lhe necessário viver bem, que é muito mais. [...] ...o morrer bem, que é o que basta para a salvação, não basta: basta, porque quem morre bem salva-se; não basta, porque para morrer bem é necessário viver bem." (t.VIII, p.373-374)

Todo esse movimento do pensamento se fecha na afirmação, que ficará por ser demonstrada ainda: "Comparadas as prudentes com as néscias, foram prudentes, porque as néscias não tiveram cuidado de que sobejasse o óleo, nem ainda de que bastasse; mas comparadas com Santa Teresa, por mais que se chamem prudentes, foram néscias; porque elas em matéria de salvação contentaram-se com o que basta; e Teresa não se contentou, nem com o que basta, nem com o que sobeja." E o pregador pede: "Dai-me atenção."

Todo o capítulo VII do sermão é a demonstração da superioridade de Santa Teresa: e a argumentação vai de degrau em degrau, separados uns dos outros pela palavra "mais". Examinemos alguns desses degraus: o primeiro, por necessidade, para compreendermos a estrutura, os outros apenas por alusão, com uma ou outra exceção. Primeiro: "Para um homem se salvar - começa com essas palavras o capítulo VII -, basta não fazer pecado mortal; e se também não fizer pecado venial, sobeja: e Santa Teresa 
não se contentou com não cometer pecado mortal, que é o que basta, nem se contentou com não cometer pecado venial advertidamente, que é o que sobeja; senão que fez voto a Deus de em todas as suas açôes buscar sempre o que fosse maior perfeição. Valentia de espírito, e resolução prodigiosa, e que de nenhum outro Santo se lê semelhante. Mais. Para uma almas se salvar, basta obedecer a Deus; e se conformar em tudo com a sua vontade, sobeja: etc. [...] Mais. Para uma alma se salvar, basta tratar da salvação própria; e se tratar também da salvação e reformação das almas alheias, dentro dos limites de seu estado, sobeja: etc. [...] Mais. [...] Para se salvar uma alma basta sofrer os trabalhos com paciência, e se chegar a tanta perfeição, que os sofra com alegria, sobeja: etc. [...] Mais. Para uma alma se salvar basta amar aos inimigos, e se chegar a lhe fazer boas obras, sobeja: etc. [...] Mais. Para uma alma se salvar basta guardar continência; e se guardar e votar virgindade perpétua, não só basta, sobeja: etc. [...] Finalmente, para uma alma se salvar basta guardar os mandamentos de Deus; e se guardar também os conselhos de Cristo, não só basta, mas sobeja: [...]." (t.VIII, p. 377-378)

Pois bem, as marcações feitas pela recorrência dos Mais delimitam cada etapa. Em cada uma, diz o pregador o que basta para a salvação e o que sobeja. E em cada caso, onde coloquei um etc., segue-se uma demonstraçáo das circunstâncias em que Santa Teresa se destacou e se sobrepôs a todos porque não se contentou nem com o que bastava e nem mesmo com o que sobejava: queria sempre Mais. Eis, completa, porque póe em cena o aspecto central da idéia de elevação -ao mesmo tempo que é um dos "degraus" ou passos argumentativos separados justamente pela palavra Mais -, a sexta etapa da argumentação, a que vem antes do "Finalmente": "Mais. Para uma alma se salvar basta guardar continência; e se guardar e votar virgindade perpétua, não só basta, mas sobeja: e Santa Teresa não só se contentou com ser continente, que é o que basta, nem só com ser virgem, que é o que sobeja; mas competindo em certo modo com a Mãe de Deus, passou a ser Virgem e Mãe juntamente. Digam-no tantos conventos de anjos humanos, uns com nome de mulheres, outros com nome de homens, que todos reconhecem a Santa Teresa por Mãe. E para que esta maternidade de Teresa 
se parecesse em tudo com a da Virgem Maria, assim Cristo teve duas gerações, uma eterna, em que nasceu de Pai sem Mãe, e outra temporal, em que nasceu de Mãe sem Pai; assim a Regra e Religião Carmelitana regenerada teve duas gerações, e dois nascimentos, um antiqüíssimo de Pai sem Mãe, quando nasceu de Elias, e outro moderno, de Mãe sem Pai, quando nasceu de Teresa." (t.VIII, p. 378)

Dessa virgem, diz ainda mais o orador: "Assim se não contentava aquele eminentíssimo espírito, aquele imenso coração, aquela alma superior a tudo, e maior que tudo; assim se não contentava com o que sobeja, assim anelava sempre mais e mais." (p. 379) E diante da possibilidade de continuar mais e mais, diz o padre: "Mas baste ao nosso discurso quanto tem corrido em seguimento deste glorioso não bastar, e descansemos um pouco..." (t.VIII, p. 379) É infinita a altura. Às finezas de Santa Teresa, favoreceu e honrou Deus com grandes e extraordinárias visões, aparecendo-lhe quase todos os dias. Também nisso ela foi superior a quase todos os Santos.

Essa sétima parte (capítulo VII) do sermão contém sete argumentos... não se alça o pregador ao oitavo. Se o fizesse, ficaria redonda a conta, ao passo que eram inúmeras as finezas de Santa Teresa, como é infinita a escada que conduz à altura. Altura - lembremos - a que Elias foi conduzido por um carro de fogo.

Mais um passo: o capítulo VIII trata da terceira superioridade de Santa Teresa em relação às virgens prudentes. "A terceira cousa em que as virgens prudentes, comparadas com Santa Teresa, foram néscias, é que as prudentes cuidaram que arriscando-se por socorrer as companheiras, corriam perigo; e Santa Teresa entendeu que tudo o que se arrisca pela caridade, quando mais se arrisca, então está mais seguro.” (t.VIII, p. 382)

$\mathrm{Na}$ demonstração desse passo, empregou o padre Vieira matéria oriunda de quatro fontes: primeira, o Antigo Testamento; segunda, a sua própria experiência recente do naufrágio; terceira, o Evangelho, na parábola do dia; e, por fim (quarta), alcançando o centro temático do sermão, a vida de Santa Teresa. Do Antigo Testamento, tomou ele o episódio de Judite e Holofernes. Com a cidade de Betúlia sitiada pelo exército de Holofernes, Judite decidiu ir sozinha ao acampamento inimigo, à tenda de Holofernes. 
"Valentes intentos, Judite - diz o padre -, mas arriscados muito. [...] E como Judite sabia que Deus é o assegurador dos riscos que se empreendem por seu amor e dos próximos, por isso fiada no seguro de Deus, não incorreu no crime dos que se põem a perigo, porque quem arrisca com seguro, não corre risco. Nem o texto da lei divina, se bem se pondera, quer dizer outra coisa. Notai: Qui amat periculum, in illo peribit: quem ama o perigo, perecerá nele. Uma coisa é entrar no perigo amando o perigo, outra coisa é entrar no perigo amando a Deus: quem entra no perigo por amor do perigo, perece nele; porque o mesmo perigo, a quem ama, e por quem se arrisca, o perde: mas quem entra no perigo por amor de Deus, não perece, nem pode perecer, porque o mesmo Deus a quem ama, e por que se arrisca, o guarda." (t.VIII, p. 383-384)

Do risco que correu no naufrágio e do perigo em que nessa viagem se meteu, tirou o padre Vieira seu segundo argumento. Ele correu o risco para ir ao reino em busca da salvação das almas dos índios do Maranhão. "E como o perigo era tomado por amor de Deus, e dos próximos; como podia faltar a segurança no mesmo perigo? $\mathrm{O}$ mesmo perigo nos livrou, ou se livrou a si mesmo. Os perigos da caridade são riscos seguros, e nos riscos seguros não pode haver perigo. [...] ...como há de temer os perigos, quem neles leva a mesma salvação que vai buscar por meio deles?” (t.VIII, p. 385-386)

E do seu naufrágio, por analogia com o perigo marítimo do profeta Jonas, passa o padre às virgens do Evangelho, transformando a tempestade em que se viu Jonas em metáfora da situação em que se viram metidas as virgens do Evangelho: "Maior tempestade padeceram as virgens no óleo das suas redomas, do que Jonas em tanto mar. Todas naufragaram... [...] Perderam-se cinco, quando se puderam salvar todas, porque não tiveram caridade as outras cinco, para se arriscarem com elas. [...] Se as prudentes se quiseram arriscar por elas, socorrendo-as, nesse mesmo risco se salvariam umas e outras: as néscias, pelo socorro que recebiam; e as prudentes, pelo socorro que davam: ou, para o dizer com mais certeza, as néscias, pelo risco de que se tiravam, e as prudentes, pelo risco em que se metiam: que quem se arrisca pela caridade, não pode correr risco." (t.VIII, p. 388)

Acima de todas, entretanto, está Santa Teresa - que fez parecerem insensatas as virgens que o Evangelho chama prudentes. Ela, sim. "Tudo 
quanto teve, quanto podia ter, arriscou Santa Teresa por amor de Deus e dos próximos." (t.VIII, p. 389) Ela arriscou a vida, arriscou a honra, arriscou a perfeição de sua alma. Ela sofreu perseguições, "quando empreendeu reduzir a Regra Carmelitana moderada ao antigo rigor e inteireza de seu primeiro Instituto". (t.VIII, p.390) Quando aconselhada a se dedicar apenas à vida contemplativa, o que lhe seria agradável pelo supremo gozo da união que teria com Deus - ela arriscou tudo, permanecendo na vida ativa, dando continuidade à empresa que começara. Sobre os riscos que corria, disse o padre Vieira: "Era muito o que arriscava, mas muito mais o que recebia. Mercês sobre mercês, favores sobre favores, glórias sobre glórias, como se os mesmos riscos fossem degraus para mais subir e crescer." (t.VIII, p.391)

Próximo degrau (o quarto): "A quarta e última coisa em que as virgens prudentes comparadas com Santa Teresa foram néscias, é que as prudentes podendo rogar ao Esposo que esperasse pelas companheiras, ou, quando menos, que lhes não fechasse as portas, não intercederam por elas: e Santa Teresa intercede sempre eficazmente por seus devotos, e por todos os que lhe pedem favor, e a ela se encomendam." (t.VIII, p.391) Nessa passagem do sermão, reaparece o número quatro - prossegue o orador: "Esta foi a quarta e última imprudência das prudentes, nas quais, se bem reparastes, acháreis que as notamos de imprudentes nas obras, imprudentes nas palavras, imprudentes nos pensamentos, imprudentes nas omissões, que são os quatro modos gerais por que só se pode pecar contra uma virtude." (t.VIII, p. 391-392) Com o exame dessas quatro imprudências, recolhe o pregador todo o seu discurso anterior, de forma resumida, enumerada, no procedimento que se conhece como "disseminação e recolha": "No primeiro [modo] foram imprudentes de obra, porque dormiram, quando haviam de vigiar: no segundo, foram imprudentes de palavras, porque disseram, não baste, quando haviam de dizer, não sobeje: no terceiro, foram imprudentes de pensamento, porque cuidaram que arriscando-se pela caridade, podiam correr perigo: no quarto, foram imprudentes de omissão, porque ao menos não pediram por quem lhes pedia. Elas não pediram nem intercederam por quem lhes pediu: e Santa Teresa, como dizia, pede e intercede eficazmente por todos os que lhe pedem e se valem de seu favor." (t.VIII, p.392) 
Por todo o sermão, até agora, até o final do capítulo IX, esteve o pregador com os olhos no céu. Desenhou-se na estrutura do discurso uma espécie de escada intelectual, em que o pensamento se vai construindo de degrau em degrau. E o panegírico cumpre sua função de exaltar Santa Teresa, colocando-a no lugar mais alto, situando-a com a distinção que merece na hierarquia celeste. Mas o discurso estava elevado e havia uma platéia: era necessário que ainda se cumprisse uma função, a que o pregador se referira no início do discurso - era preciso pôr os olhos na Terra. Estavam os homens na terra, e Santa Teresa no céu; ao voltar-se para o auditório, no capitulo X (e último) do sermão, o padre Vieira executa e cumpre uma função essencial a todo o gênero oratório - consiste essa função no apelo ao ouvinte, na inclusão dele, ouvinte, na estrutura do discurso. É o que resta por fazer.

No capítulo X discorre o sermonista sobre as insensatez dos homens, seus ouvintes, que, na escala proposta, se situam abaixo das virgens néscias do Evangelho. Diz ele: "E para que conheçamos todos quanta necessidade temos dos socorros e auxílios superiores; voltemos um pouco sobre nós os olhos, que até agora tivemos postos em Santa Teresa, e veremos para maior glória sua, e maior confusão nossa, que se as prudentes comparadas com ela foram néscias, as néscias comparadas conosco foram prudentes. Tão néscios e tão imprudentes somos nas matérias de nossa salvação! As prudentes, como vimos, em comparação de Santa Teresa, foram quatro vezes néscias: as néscias em nossa comparação, foram oito vezes prudentes." (t.VIII, p.394)

O primeiro ponto em que os cristãos, ou os homens, são néscios em relação às virgens, é que elas, para se salvarem, escolheram o estado de virgens, ao passo que os homens vivem mergulhados na torpeza, na sensualidade, no adultério, nas afeições sacrílegas. O segundo ponto, ou a "segunda prudência" das néscias, que falta aos homens, é que elas saíram de suas casas, mas saíram para acompanhar o Esposo e a Esposa, ao passo que os homens saem, uns só por sair (o que é perda de tempo), outros saem para ver e ser vistos (o que os faz perderem suas próprias almas e as alheias), outros, ainda, saem para jogar (o que lhes leva o dinheiro), saem para pleitear (o que lhes leva a fama), saem para murmurar (o que lhes leva a consciência). A terceira prudência das néscias é que elas dormiram, mas 
acordaram ao primeiro sinal de que isso era necessário, ao passo que os homens vivem adormecidos no pecado e, por mais que sejam chamados, continuam a dormir. A quarta prudência delas (das néscias) é que elas ornaram suas lâmpadas, ao passo que os homens se enfeitam a si mesmos (por vaidade do corpo). A quinta prudência consistiu em elas vencerem a repugnância de pedir alguma coisa a suas iguais e pedirem, ao passo que, entre os homens, muitos há que preferem roubar a pedir, muitos outros preferem vender a alma ou o corpo a pedir - e o que é pior, muitos não pedem a Deus, nem remédio para a necessidade, nem socorro para a tentação, nem perdão para o pecado. A sexta prudência foi o aceitarem o conselho de ir comprar mais óleo para suas lâmpadas, ao passo que os homens não ouvem conselhos nem dos confessores, nem dos pais, nem dos amigos, nem dos livros, nem dos anjos da guarda, nem dos exemplos que o mundo dá. A sétima prudência delas é terem ido comprar o óleo para suas lâmpadas - sem reparar no trabalho nem no dinheiro -, ao passo que nós, que compramos de tudo, e compramos coisas caríssimas e desnecessárias, só o céu não queremos comprar. A oitava prudência foi as virgens néscias terem voltado, terem batido à porta do Céu e terem chamado pelo Esposo, ao passo que nós não voltamos, nem viemos, nem chamamos.

Diz o pregador: "Elas vieram, bateram, e chamaram; nós nem viemos, nem batemos, nem chamamos: antes, está a representação e a tragédia tão trocada em tudo, que Deus é o que vem, e nós fugimos; Deus o que chama, e nós não respondemos; Deus o que bate, e nós não abrimos." (t.VIII, p. 397) As virgens prudentes, que tiveram as lâmpadas acesas com suas boas obras, entraram no céu. "Pois se não tendes boas obras, e sem boas obras não vos podeis salvar; essa esperança que tendes de vossa salvação, em que a fundais? Há Deus de faltar à sua justiça? Há de mudar suas leis por amor de vós? Dir-me-eis, que ainda que não tendes agora as boas obras, que tendes propósitos de as fazer depois. E se antes desse depois vier o Esposo: Dum autem irent emere, venit Sponsus? Se antes desse depois vier a morte? Se antes desse depois vos pediram conta? Atreveis-vos a estar no Inferno para sempre? Torno a dizer: atreveis-vos a estar no Inferno, a arder naquelas chamas para sempre? Este para sempre repetia muitas vezes Santa 
Teresa, ainda sendo muito menina, e este para sempre foi princípio da sua oração, e o primeiro fundamento da sua santidade. Com este para sempre me quero despedir de vós, e que este para sempre vos fique soando nos ouvidos, e imprimindo-se nas memórias: para sempre, para sempre, para sempre." (t.VIII, p.398)

Fica, assim, demonstrado que o "Sermão de Santa Teresa", como tantos outros do padre Vieira, é constatação e prova desta afirmação de Fernando Pessoa: "Antônio Vieira é de fato o maior prosador - direi mais, é o maior artista - da língua portuguesa." (p.343)

\section{Referências bibliográficas}

AZEVEDO, João Lúcio de. História de Antônio Vieira. Lisboa: Clássica, 1931. $2 \mathrm{t}$.

CRUZ, Sor Juana Inés de la. Carta Atenagórica. In: Obras completas de Sor Juana Inés de la Cruz IV: Comedias, sainetes y prosa. México: Fondo de Cultura Económica, 1995. p.412-439.

LIMA JÚNIOR, Augusto de. História de Nossa Senhora em Minas Gerais (Origens das principais invocações). Belo Horizonte: Imprensa Oficial, 1956.

PAZ, Octavio. Libertad bajo palabra (Obra poética 1935-1957). México: Fondo de Cultura Económica, 1970.

PESSOA, Fernando. Obras em prosa. Rio de Janeiro: Nova Aguilar, 1982.

REBOUL, Olivier. Introdução à retórica. São Paulo: Martins Fontes, 1998.

SARTRE, Jean-Paul. O ser e o nada (Ensaio de ontologia fenomenológica). Petrópolis: Vozes, 1997.

VIEIRA, Antônio. Cartas. Coord. e An. João Lúcio de Azevedo. Lisboa: Imprensa Nacional, 1970. 3t.

VIEIRA, Antônio. Sermões. Porto: Lello \& Irmão, 1959. 15 t. 


\section{Resumo}

Este artigo analisa o "Sermão de Santa Teresa", do padre Antônio Vieira.

\section{Abstract}

This article analyses a panegyric to St. Teresa of Jesus, by Antônio Vieira. 